\title{
Prevalence and correlates of abscesses among a cohort of injection drug users Elisa Lloyd-Smith ${ }^{1,2}$, Thomas Kerr',3, Robert S Hogg1,2,3, Kathy Li², Julio SG Montaner 2,3 and Evan Wood*2,3
}

Address: ${ }^{1}$ Department of Health Care and Epidemiology, Faculty of Medicine; University of British Columbia, 5804 Fairview Ave, Vancouver, Canada, ${ }^{2}$ British Columbia Centre for Excellence in HIV/AIDS; St. Paul's Hospital, 608-1081 Burrard Street, Vancouver, Canada and ${ }^{3}$ Department of Medicine; University of British Columbia, 3300 - 950 W. 10th Ave, Vancouver, Canada

Email: Elisa Lloyd-Smith - esmith@cfenet.ubc.ca; Thomas Kerr - tkerr@cfenet.ubc.ca; Robert S Hogg - bobhogg@cfenet.ubc.ca; Kathy Li - kathyli@cfenet.ubc.ca; Julio SG Montaner - jmontaner@cfenet.ubc.ca; Evan Wood* - ewood@cfenet.ubc.ca

* Corresponding author

Published: 10 November 2005

Harm Reduction Journal 2005, 2:24 doi:10.1186/1477-75/7-2-24
Received: 20 July 2005

Accepted: 10 November 2005

This article is available from: http://www.harmreductionjournal.com/content/2/I/24

(c) 2005 Lloyd-Smith et al; licensee BioMed Central Ltd.

This is an Open Access article distributed under the terms of the Creative Commons Attribution License (http://creativecommons.org/licenses/by/2.0), which permits unrestricted use, distribution, and reproduction in any medium, provided the original work is properly cited.

\begin{abstract}
Recent studies have indicated that injection-related infections such as abscesses and cellulitis account for the majority of emergency room visits and acute hospitalizations accrued by local injection drug users. The objective of this analysis was to examine the prevalence and correlates of developing an abscess among a cohort of injection drug users in Vancouver and to identify sociodemographic and drug use variables associated with abscesses at baseline. We examined abscesses among participants enrolled in a prospective cohort of injection drug users. Categorical variables were analyzed using the Pearson's chi-square test and continuous variables were analyzed using the Wilcoxon signed rank test. Among I 585 baseline participants, 34। (21.5\%) reported having an abscess in the last six months. In a logistic regression model that adjusted for all variables that were associated with having an abscess at $p<0.1$ in univariate analyses, female gender [odds ratio (OR) $=1.7,[95 \% \mathrm{Cl}: 1.2-2.4] ; p=0.002)$, recent incarceration $(\mathrm{OR}=1.7,[95 \% \mathrm{Cl}: 1.3-2.2] ; p<0.001)$, sex trade involvement $(\mathrm{OR}=1.4[95 \% \mathrm{Cl}: 1.0-2.0] ; p=0.03)$, frequent cocaine use $(\mathrm{OR}=1.5$ [95\%Cl: $1.2-2.0] ; p=0.002)$ and HIV serostatus $(\mathrm{OR}=1.5,[95 \% \mathrm{Cl}: 1.2-2.0] ; \mathrm{p}=0.003)$ were positively associated with having an abscess. Explanations for these associations require further study, and interventions are needed to address this highly prevalent concern.
\end{abstract}

\section{Findings}

The Downtown Eastside of Vancouver, Canada is a community characterized by high rates of HIV among injection drug users (IDU), and is also the setting of one of North America's highest volume needle exchange program (NEP) [1]. Recent studies have indicated that injection-related infections, such as abscesses and cellulitis, account for the majority of emergency room visits and acute hospitalizations in local IDU [2,3]. Factors associ- ated with the development of abscesses among IDU have not been well described in settings with widespread access to sterile injecting equipment and high rates of HIV infection. In particular, abscesses are not characterized in Vancouver. However, abscesses can lead to serious complications including but not limited to osteomyelitis [4], endocarditis [5-7], and septicemia [8,9]. An ongoing prospective cohort study of IDU in Vancouver allowed for 
Table I: Baseline demographic characteristics of IDU stratified by having an abscess in the past six months.

\begin{tabular}{|c|c|c|c|c|}
\hline Characteristic & $\begin{array}{l}\text { No abscess past six } \\
\text { months } n=I 244\end{array}$ & $\begin{array}{l}\text { Abscess past six } \\
\text { months } n=34 I\end{array}$ & Odds Ratio $(95 \% \mathrm{Cl})$ & p-value \\
\hline \multicolumn{5}{|l|}{ Gender } \\
\hline Male & $848(68.2)$ & $162(47.5)$ & & \\
\hline Female & $396(31.8)$ & $179(52.5)$ & $2.4(1.9-3.0)$ & $<0.001$ \\
\hline \multicolumn{5}{|l|}{ HIV status } \\
\hline Negative & 919 (73.9) & $209(6 \mid .3)$ & & \\
\hline Positive & $325(26.1)$ & $132(38.7)$ & I.7 (I.4-2.3) & $<0.001$ \\
\hline \multicolumn{5}{|c|}{ Unstable housing* } \\
\hline No & $492(39.5)$ & $109(32.0)$ & & \\
\hline Yes & $752(60.5)$ & $387(68.0)$ & $1.3(1.1-1.8)$ & 0.011 \\
\hline \multicolumn{5}{|c|}{ Recent incarceration* } \\
\hline No & $86 I(69.2)$ & $196(57.5)$ & & \\
\hline Yes & $383(30.8)$ & $145(42.5)$ & $1.7(1.3-2.1)$ & $<0.001$ \\
\hline \multicolumn{5}{|l|}{ DTES residence* } \\
\hline No & $552(44.4)$ & $121(35.5)$ & & \\
\hline Yes & $692(55.6)$ & $220(64.5)$ & $1.5(1.1-1.9)$ & 0.003 \\
\hline \multicolumn{5}{|c|}{ Sex trade involved* } \\
\hline No & $942(75.7)$ & 191 (56.0) & & \\
\hline Yes & $302(24.3)$ & $150(44.0)$ & $2.4(1.9-3.1)$ & $<0.001$ \\
\hline \multicolumn{5}{|l|}{ Heroin use* } \\
\hline Less than daily & $840(67.5)$ & $203(59.5)$ & & \\
\hline Daily use & $404(32.5)$ & $138(40.5)$ & $1.4(1.1-1.8)$ & 0.006 \\
\hline \multicolumn{5}{|l|}{ Cocaine use* } \\
\hline Less than daily & $858(69.0)$ & $182(53.4)$ & & \\
\hline Daily use & $386(31.0)$ & $159(46.6)$ & $1.9(1.5-2.5)$ & $<0.001$ \\
\hline
\end{tabular}

Note: IDU = injection drug user, DTES = Downtown Eastside Residence. *Indicates behaviour during the six month period prior to the baseline interview.

an examination of the prevalence and factors associated having an abscess in this setting.

For these analyses, data was collected through the Vancouver Injection Drug Users Study (VIDUS), a prospective cohort that has been previously described in detail [1]. Data from participants who completed baseline questionnaires between May 1, 1996 and May 31, 2004 were evaluated for the present study. Participants were categorized on the basis of whether or not they reported having an abscess lasting for more than three days during the previous six months. Univariate and multivariable statistics were applied to determine factors associated with developing an abscess in the previous six months. Categorical variables were analyzed using the Pearson's chi-square test, and continuous variables were analyzed using the Wilcoxon signed rank test. Variables associated with having an abscess at $\mathrm{p}<0.1$ were considered in a subsequent logistic regression analysis.

Socio-demographic and drug-using characteristics considered in these analyses as potential risk factors included: age, gender, HIV status, unstable housing, residing in Vancouver's Downtown Eastside, incarceration in the previous six months, sex trade involvement, borrowing and lending of syringes, frequent heroin and cocaine injec- tion, binge drug use, public drug injection, requiring help with injections, and methadone maintenance therapy use. Unstable housing was defined as living in a single room occupancy hotel, transitional living arrangements, or being homeless. Individuals who reported injecting cocaine or heroin once or more a day were defined as frequent heroin and cocaine injectors. Bingeing was defined as periods in which drugs were injected more often than usual. Variable definitions were consistent with previous analyses [1].

Overall, of the 1585 baseline VIDUS participants, 341 $(21.5 \%)$ reported having an abscess in the last six months. The factors associated with having an abscess at $p<0.1$ in univariate analyses included: female gender $(\mathrm{OR}=2.4$, [95\%CI: $1.8-3.0] ; p<0.001)$; unstable housing (OR = 1.3, [95\%CI: $1.1-1.8] ; p=0.01)$; recent incarceration $(\mathrm{OR}=1.7,[95 \% \mathrm{CI}: 1.3-2.1] ; p<0.001)$; sex trade involvement $(\mathrm{OR}=2.4$, [95\%CI: $1.9-3.1] ; p<0.001)$; frequent heroin use $(\mathrm{OR}=1.4,[95 \% \mathrm{CI}: 1.1-1.8] ; p=$ 0.006 ); frequent cocaine use (OR $=1.9,[95 \% \mathrm{CI}: 1.5-$ $2.5] ; p<0.001)$; residing in Vancouver's Downtown Eastside (OR $=1.5$, [95\%CI: $1.1-1.9] ; p=0.003)$; and HIV serostatus $(\mathrm{OR}=1.8$, [95\%CI: $1.4-2.3] ; p<0.001)$. Table 1 shows the baseline demographic characteristics of IDU stratified by having an abscess or not in the past six 
Table 2: Logistic regression of factors associated with having an abscess

\begin{tabular}{|c|c|c|c|}
\hline Characteristic & Odds Ratio & 95\% C.I. & $p$-value \\
\hline \multicolumn{4}{|l|}{ Gender } \\
\hline (Female vs Male) & 1.7 & $(1.4-2.4)$ & 0.002 \\
\hline \multicolumn{4}{|c|}{ Frequent cocaine use } \\
\hline (Yes vs No) & 1.5 & $(1.2-2.0)$ & 0.002 \\
\hline \multicolumn{4}{|c|}{ Recent incarceration } \\
\hline (Yes vs No) & 1.7 & $(1.3-2.2)$ & $<0.001$ \\
\hline \multicolumn{4}{|c|}{ Sex trade involvement } \\
\hline (Yes vs No) & 1.5 & $(I . I-2.1)$ & 0.030 \\
\hline \multicolumn{4}{|l|}{ HIV serostatus } \\
\hline (Yes vs No) & 1.5 & $(1.2-2.0)$ & 0.003 \\
\hline
\end{tabular}

months for significant variables considered in the univariate analysis.

As shown in Table 2, in a logistic regression model that adjusted for all variables that were associated with having an abscess at $p<0.1$ in univariate analyses, female gender [odds ratio $(\mathrm{OR})=1.7$, [95\% CI: $1.2-2.4] ; p=0.002$ ), recent incarceration $(\mathrm{OR}=1.7,[95 \% \mathrm{CI}: 1.3-2.2] ; p<$ $0.001)$, sex trade involvement $(\mathrm{OR}=1.4$ [95\% CI: 1.0 $2.0] ; p=0.030)$, frequent cocaine use $(\mathrm{OR}=1.5[95 \% \mathrm{CI}$ : $1.2-2.0] ; p=0.002)$ and HIV serostatus (OR $=1.5,[95 \%$ CI: $1.2-2.0] ; p=0.003$ ) were independently and positively associated with having an abscess.

Our results indicate female gender, recent incarceration, sex trade involvement, frequent cocaine use and HIV serostatus are positively associated with developing an abscess. These results are consistent with results from a study in Amsterdam where female gender and prostitution among women, as well as, frequent cocaine use were identified as independently and positively associated with skin abscesses [10]. In addition, the association between HIV-positive status and having an abscess has been noted elsewhere, and is understandable given that HIV-positive individuals may have a heightened susceptibility to bacterial infections $[11,12]$. Furthermore, high risk of infectious complications, such as endocarditis from abscesses [10], occur among HIV infected individuals [11].

Abscesses are a common consequence of injection drug use [13-15]. The present study demonstrates that widespread access to sterile syringes through high-volume needle exchanges and a medically supervised safer injection facility may not be sufficient to prevent high rates of abscesses among IDU in Vancouver. In addition, our findings demonstrate the need for educational and structural interventions to improve rates of sterile injecting $[16,17]$.

Our study has limitations. First, although previous research has indicated that the VIDUS cohort is represent- ative of Vancouver IDU [18], VIDUS is not a random sample. Second, the study relied on self-report, and therefore, the results could be susceptible to socially desirable reporting although we know of no reason why reporting abscesses would be subject to this concern. Third, the cross-sectional nature of this study precludes any conclusions regarding causal relationships between the variables studied and the outcome of interest. Further prospective study is needed to assess predictors of abscess in this setting.

In summary, $21.5 \%$ of IDU participating in this study reported having an abscess in the previous six months. Results from this study indicate female gender, recent incarceration, sex trade involvement, frequent cocaine use and HIV serostatus are independently and positively associated with developing an abscess in injection drug users. Given the potential health complications arising from bacterial infections our findings highlight the need for the expansion of programs to promote safer injection practices.

\section{Competing interests}

The author(s) declare that they have no competing interests.

\section{Authors' contributions}

Elisa Lloyd-Smith, Thomas Kerr and Evan Wood designed the study. Kathy Li conducted the statistical analysis. Elisa Lloyd-Smith drafted the manuscript and incorporated all suggestions. All coauthors made significant contributions to the conception and design of the analyses, interpretation of the data and drafting of the manuscript, and they all approved the version to be published.

\section{Acknowledgements}

We would particularly like to thank the VIDUS participants for their willingness to participate in the study. We also thank Drs. Kevin Craib, Richard Harrigan, Cari Miller, David Patrick, Mark Tyndall, Martin Schechter, Will Small, Patricia Spittal, \& Steffanie Strathdee, for their research assistance, and Bonnie Devlin, John Charette, Caitlin Johnston, Vanessa Volkommer, 
Steve Kain, Dave Isham, Nancy Lalibarte, Sue Currie and Peter Vann for their administrative assistance. The study was supported by the US National Institutes of Health (ROI DA0I I59I-04AI) and ClHR grant (MOP-67262). Elisa Lloyd-Smith is supported by a Junior Graduate Studentship from the Michael Smith Foundation for Health Research.

\section{References}

I. Wood E, Tyndall MW, Spittal PM, Li K, Hogg RS, Montaner JS, O'Shaughnessy MV, Schechter MT: Factors associated with persistent high-risk syringe sharing in the presence of an established needle exchange programme. Aids 2002, 16:941-943.

2. Kerr T, Wood E, Grafstein E, Ishida T, Shannon K, Lai C, Montaner J, Tyndall MW: High rates of primary care and emergency department use among injection drug users in Vancouver. J Public Health (Oxf) 2004.

3. Palepu A, Tyndall MW, Leon H, Muller J, O'Shaughnessy MV, Schechter MT, Anis AH: Hospital utilization and costs in a cohort of injection drug users. Cmaj 200I, 165:4I5-420.

4. Roszler MH, McCarroll KA, Donovan KR, Rashid T, Kling GA: The groin hit: complications of intravenous drug abuse. Radiographics 1989, 9:487-508.

5. DeWitt DE, Paauw DS: Endocarditis in injection drug users. Am Fam Physician 1996, 53:2045-2049.

6. DiNubile MJ: Short-course antibiotic therapy for right-sided endocarditis caused by Staphylococcus aureus in injection drug users. Ann Intern Med 1994, I 2 I:873-876.

7. Miro JM, Moreno A, Mestres CA: Infective Endocarditis in Intravenous Drug Abusers. Curr Infect Dis Rep 2003, 5:307-3I6.

8. Hankins C, Palmer D, Singh R: Unintended subcutaneous and intramuscular injection by drug users. Cmaj 2000, 163:1425-1426.

9. Williamson N, Archibald C, Van Vliet JS: Unexplained deaths among injection drug users: a case of probable Clostridium myonecrosis. Cmaj 200I, 165:609-6II.

10. Spijkerman IJ, van Ameijden EJ, Mientjes GH, Coutinho RA, van den Hoek A: Human immunodeficiency virus infection and other risk factors for skin abscesses and endocarditis among injection drug users. J Clin Epidemiol 1996, 49: I I49- I I54.

II. Selwyn PA, Alcabes P, Hartel D, Buono D, Schoenbaum EE, Klein RS, Davenny K, Friedland GH: Clinical manifestations and predictors of disease progression in drug users with human immunodeficiency virus infection. N Engl J Med 1992, 327:1697-I703.

12. Flanigan TP, Hogan JW, Smith D, Schoenbaum E, Vlahov D, Schuman $P$, Mayer K: Self-reported bacterial infections among women with or at risk for human immunodeficiency virus infection. Clin Infect Dis 1999, 29:608-6/2.

13. Brown PD, Ebright JR: Skin and Soft Tissue Infections in Injection Drug Users. Curr Infect Dis Rep 2002, 4:415-419.

14. Murphy EL, DeVita D, Liu H, Vittinghoff E, Leung P, Ciccarone DH, Edlin BR: Risk factors for skin and soft-tissue abscesses among injection drug users: a case-control study. Clin Infect Dis 200I, 33:35-40.

15. Binswanger IA, Kral AH, Bluthenthal RN, Rybold DJ, Edlin BR: High prevalence of abscesses and cellulitis among communityrecruited injection drug users in San Francisco. Clin Infect Dis 2000, 30:579-581.

16. Ross MW, Wodak A, Stowe A, Gold J: Explanations for sharing injection equipment in injecting drug users and barriers to safer drug use. Addiction 1994, 89:473-479.

17. Wood E, Kerr T, Montaner IS, Strathdee SA, Wodak A, Hankins CA, Schechter MT, Tyndall MW: Rationale for evaluating North America's first medically supervised safer injecting facility. Lancet Infect Dis 2004, 4:301-306.

18. Tyndall MW, Craib KJ, Currie S, Li K, O'Shaughnessy MV, Schechter MT: Impact of HIV infection on mortality in a cohort of injection drug users. J Acquir Immune Defic Syndr 200 I, 28:35 I-357.

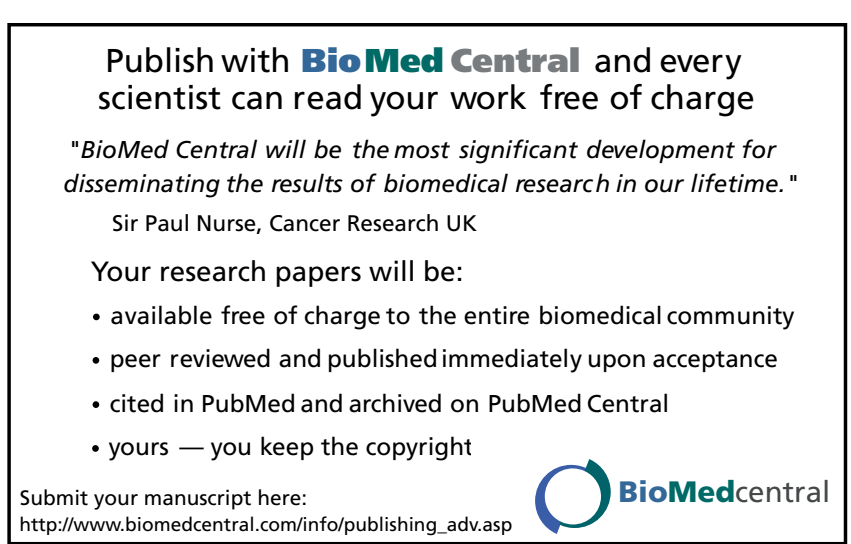

